\title{
CUSTOMARY LAW IN THE NEW AFRICAN STATES
}

\section{LIOYD FALLERS*}

\section{InTRODUCTION}

Among the long list of intractable problems faced by the new independent states of Africa, by no means the least severe is that of creating national legal systems out of the welter of indigenous and introduced bodies of law with which they come to independence. Bodies of customary law have survived, and in some cases have even been strengthened, during the period of colonial administration; European and, in some instances, Near Eastern and Asian elements have been added to the potpourri. As members of the various communities to which these diverse bodies of law apply increasingly marry, contract with, and rob one another, the potentiality for conflict of laws is enormous. In relatively few cases have satisfactory means of reconciling them been developed.

This legal pluralism is, of course, merely the legal aspect of the general cultural fragmentation which is so characteristic of the new African states. Consisting of congeries of traditional polities-some tiny clusters of a few villages, others great kingdoms numbering their subjects in the millions-thrown together by European diplomacy in the nineteenth century, the new states have little common culture to unite them. Over large areas of Asia and the Near East, and Muslim North Africa as well, otherwise diverse peoples are given a measure of unity-including sometimes unity of law-by the influence of the great multi-ethnic "world religions": Islam, Buddhism, and Hinduism. The peoples of sub-Saharan Africa, however, lack such bases for common loyalty and identification. To be sure, there is over large areas a great deal of similarity of culture and language. For example, by far the larger part of the continent south of the Sudan belt is populated by speakers of Bantu and related languages whose historical differentiation, linguists tell us, is very recent-perhaps a matter of only a very few thousand years. ${ }^{1}$ But, not being embodied in an elite literary tradition which might have articulated and concretized them, these elements of common culture have little unifying influence to contribute to the new states. Before the establishment of colonial rule, the thousands of distinct African polities confronted one another as autonomous and often hostile entities; to a great extent, they still do.

Such unity as the sub-Saharan states possess today is in large part a product of the colonial experience-of the common Western education of the elites and of the common reaction against colonial rule and against the centuries of slavery which preceded it. This unity, however, is both a doubtful and wasting asset: doubtful

* Ph.B. 1946, M.A. I949, Ph.D. 1953, University of Chicago. Associate Professor, Department of Anthropology, University of Chicago.

${ }^{1}$ Greenberg, Africa as a Linguistic Area, in Wirliam R. Bascon \& Melvilie J. Herskovits, Continutty and Change in African Cultures (I958). 
because community based upon a language and culture borrowed from the colonial rulers is ideologically unsatisfying, tending to perpetuate the sense of dependence and inferiority which so torments African leaders; and wasting because, as the years after independence roll on, feelings of brotherhood based upon common opposition tend to wane. A deeper and more enduring sense of nationhood and citizenship can only develop slowly through the confrontation of common problems and through the ideological creativity of leaders who are able to synthesize new national culturescultures which are modern in attitude but which also draw upon the underlying, but previously unarticulated, cultural unities of traditional Africa. Such conceptions as "negritude" and "African personality" may be understood as the initial and as yet rather vague attempts at such synthesis.

At present, however, the overriding cultural-and legal-reality for the vast majority of village-dwelling Africans is the traditional ethnic group. If one has in mind this tribally-oriented majority, and not the small minority whose primary loyalties are wider, then the relevant boundaries between bodies of law are not the familiar political frontiers shown on most maps but rather the many times more numerous boundaries between traditional tribes and kingdoms which appear on the maps of anthropologists. ${ }^{2}$

The problems of legal administration involved in reconciling these dozens-in some states, hundreds-of customary jurisdictions among themselves and with the more recently introduced bodies of law are lawyers' problems, upon which an anthropologist is very ill-equipped to comment. His specialty is rather the microscopic view-the detailed analysis of how a particular body of customary law operates today, at the moment of independence, to provide justice for ordinary members of an African community in the conflicts that commonly take them into court. ${ }^{3}$

On one level, such an analysis tells us only about the law of the community in question; it cannot tell us much about the substance of "African law" in general for, as the above remarks indicate, "African law" in this sense does not exist. This does not mean, however, that we can learn nothing of wider relevance from the examination of law in a particular African community. For while the substantive customary law is of local application only, the degree to which it continues to order relations among members of the community, and the ways in which it responds to changes in these relations, may be quite typical. To the extent to which this is so, an assessment of the present state of customary law in a contemporary African community may perhaps assist lawyers in thinking about the broader problems of legal pluralism at the level of the new national states. If customary law remains vigorous in the life of the people and if it is flexible enough to adapt to new circumstances, then the architects of the new national legal systems may prefer to seek means of incorporating it and equipping it with the tools for further evolution, rather than sweeping it away in a burst of legislative enthusiasm.

\footnotetext{
${ }^{2}$ See, for example, George P. Murdock, Africa: Its Peoples and Their Culture History (1959).

${ }^{3}$ Perhaps the best examples of such studies are Max Gluckman, The Judicial Process Amono the Barotse (1955), and P. J. Bohannan, Justice and Judgment Among the Tiv (1959).
} 


\section{A Day IN Court}

Perhaps the best way of conveying some sense of the present condition of customary law is by describing an actual case as it comes before a court and is adjudicated. The material that we shall present comes from Busoga District in the Eastern Province of Uganda, then a British protectorate. ${ }^{4}$ While of course each area has its peculiarities, the position of customary law and customary courts in Busoga may be taken as broadly representative of that in most African countries presently or formerly under British administration.

The reader should imagine a long, low-thatched building-the courthouse-with whitewashed mud-and-wattle walls, open all around at window level so that those who cannot find seats on the rows of wooden benches inside can look in. Although the court is not yet in session, dozens of bicycles are stacked against the wall outside and the room is already crowded, for litigation is a pre-eminently public activity and a popular one, giving ample scope for the people's love of intricate and eloquent rhetoric. Among the majority who have come, not to participate but simply to form an appreciative audience, are gray-haired elders who through years of attendance at court have become connoisseurs of the litigious art, wide-eyed boys eager to further their legal education, and nursing mothers for whose infants such days in court will be among their earliest remembered experiences. Chickens wander, clucking, in and out of doorways; and a passing herdsman stops to listen to the proceedings, leaning against a tree while his cattle graze on the courthouse lawn.

For everyone present the experience will be not merely enjoyable but also instructive, because in the customary courts every man is his own advocate. And since one in every seven adult males is likely to appear in court as a principal each year, the lessons learned today will find ready application. ${ }^{5}$ The audience is therefore attentive as the judges, formally attired in their long white gowns and Western-style jackets, file in and take their places at the table on the dais at the end of the hall: the sub-county chief and chairman of the court; two of the six parish ${ }^{6}$ chiefs of the sub-county, serving on rotation; and two of a panel of elected members, also serving on rotation. As each speaker, litigant or witness, addresses the bench, he bows respectfully to the judges and speaks with as much gravity and eloquence as he can muster.

Today there come before the court two peasant farmers, Sulaiti Mukama and Kaswabuli, both of the village of Bukona. ${ }^{7}$ They are contending for a piece of land-

\footnotetext{
- The material reported in this paper was gathered during 1950-1952, while the writer was serving as a Research Fellow of the East African Institute of Social Research. Uganda became an independent state on October 9, 1962. N.Y. Times, Oct. 9, I962, p. 8, col. I.

This calculation is for one county of Busoga District in which the rate of litigation is not unusually high.

"The term "parish" has no ecclesiastical reference.

${ }^{7}$ Case No. 7I, 195I, Sub-County Court of Ssaabawaali, County of Kigulu. The quotations given below are translations from the written case record.
} 
a kibanja, as the Basoga ${ }^{8}$ call a complete peasant's holding, with its plantain garden from which comes the staple food, its tract of fallow, and its plots for peanuts, maize, cotton, and other annual food and cash crops. Although Sulaiti Mukama is in possession of the land, he nevertheless appears as "accuser," having laid his case before the chief some days earlier and having had it entered on the docket. The reason is this: while this sub-county court is the lowest "court of record"-the lowest court recognized by the statutes of the Uganda Protectorate-there are also three lower levels of "courts" presided over, in ascending order, by the headman of the sub-village, the headman of the village, and the chief of the parish (an area containing several villages). Although no statute says it must do so, each case must, in customary practice, pass through this hierarchy of unofficial courts before reaching the subcounty court, and many are successfully arbitrated in the process. In the case before us, however, Kaswabuli has secured a favorable judgment from these lower courts and Sulaiti Mukama has refused to accept it. From the point of view of the litigants, therefore, the case comes to the sub-county court on "appeal"; and Sulaiti Mukama, who occupies the land in question, is the accuser.

As the case opens, the court clerk, who will laboriously record the proceedings in longhand in the local language, reads Sulaiti Mukama's charge against Kaswabuli: "For taking my kibanja, which was allotted to me by the sub-village headman, Semeyi." The court then addresses the accused, Kaswabuli:

Q: Do you agree to contest this case and do you say that you will win or lose? You do not have to answer, but anything you say will be used as evidence by the court.

Here is a charge to the accused clearly taken from British practice, but we may note that he is not sworn to truthfulness. In a peasant community it is not so much the "facts" that are in question; probably everyone knows these. Consequently, it is assumed in Busoga courts that an honorable man will lie on his own behalf; the court is expected to discover where substantial truth and justice lie through clever questioning of everyone concerned. ${ }^{9}$

The accused then states his case:

A: I agree to contest and I say that I will win, because Sulaiti Mukama has no kibanja. The kibanja which the headman allotted to him was mine. I inherited it from my grandfather, Kikoma, and the village headman who allotted it to him was Mwoga. After Kikoma's death my father, Nandere, took it, and after my father's death, I inherited it. But since my father died while I was still young, the sub-village headman, Semeyi, tried to take part of it to give to Sulaiti Mukama. When I grew up, I accused the sub-village headman before the village headman and $I$ won the case. The village

8 The country is called "Busoga," the people "Basoga."

There are exceptions to this: When a man addresses the court as a formal witness to a contract, he is expected to tell the truth. 
headman sent representatives, who marked out and returned to me the part which had been given to Sulaiti Mukama. Eria Bakali is my witness who can prove that the kibanja is mine.

Having heard from Kaswabuli, the court returns to Sulaiti Mukama, the accuser, and similarly charges him: "Do you agree to contest...."

A: I agree to contest and I say that I shall win, because the kibanja is mine. It was given to me by the sub-village headman, Semeyi, and I have spent twenty-eight years in it. When he says that he went and accused me to the village headman, he is lying. He only went to inform the village headman in a friendly way and the village headman made a case of it. From the information he had from Kaswabuli, the headman sent some representatives to go and give Kaswabuli the kibanja. But the sub-village headman who had given it to me, Semeyi, was not present when they uprooted the old boundary trees and planted new ones. All these things were done also in my absence, while I was on a journey. But when I returned I made a case against them in the parish chief's court and he called the village headman and Kaswabuli, but they refused to appear. To further prove that the kibanja presently in question is mine, Kaswabuli successfully claimed the neighboring kibanja at the time of Semeyi's death and was given representatives from this court to plant boundary trees for him. Another thing that proves it is that Kaswabuli has never taken the matter of this piece of land before the lineage council of Semeyi, the sub-village headman who allotted the land to me, since Semeyi's death. Walajja is my witness who can prove that the kibanja is mine, for he is the one who allotted it to me.

Now both principals have stated their cases and the court must proceed to question them and their witnesses in order to arrive at a decision. Meanwhile, however, there are elements in the initial statements which we cannot understand without further information. In order to appreciate what these statements will have meant to the court and the lines of questioning which it will now follow, we must explain some of the elements of land law and village government in Busoga.

It will have been clear from the initial statements that a number of parties are involved in the distribution of rights in land. Both principals have spoken of the land having been "allotted" by sub-village headmen. Kaswabuli has spoken of "inheriting" the land. Sulaiti Mukama has charged Kaswabuli with not "taking the matter to the lineage council" and has confused us by referring to two different men as the headman by whom he was allotted the land. Also, both village and sub-village headmen seem to have been involved. What does all this mean?

First of all, each village in Busoga has a hereditary headman, and each is divided into sub-villages, also with hereditary headmen. A peasant who wishes to take up land goes to the sub-village headman who, if he has a vacant plot in his area, 
may allot it to him in exchange for a sum of money and a symbolic payment of a chicken in recognition of the headman's overlordship. When the peasant dies, the land passes to his heir without further reference to the sub-village headman, but if he should die without leaving an heir or leave the land vacant for more than a season or two, the headman may repossess the land for allotment to someone else. The headman of the whole village should be notified of, and give his consent to, allotments made by his sub-village headmen. "Inheritance," in the case of both the peasant's plot and the headman's office, means inheritance within a patrilineal descent group-a lineage; but there is no fixed order of succession. The emphasis is upon the corporate rights of the lineage, not the right of the individual to succession. The lineage council, which meets at the funeral feast a few weeks after a man's death, may choose any of his sons, or even brothers or brothers' sons, whom it may regard as most suitable to be heir. Since rights in land and office thus reside ultimately in the lineage as a corporation, a person who has a claim against the deceased should present it before the council meeting at the funeral feast. Sulaiti Mukama is arguing that if Kaswabuli had a valid claim against land allocated by Semeyi, the sub-village headman, he should have pressed it at Semeyi's death. This same emphasis upon the rights of the lineage appears in Sulaiti Mukama's reference to both Semeyi and Walajja as the "headman who allotted the land to me." Semeyi has died and Walajja is his successor; the identification is so complete that Walajja may be spoken of as having done things, in his official capacity, that were actually done by his predecessor.

Thus, rights in a piece of land are distributed among six parties: the village headman, the sub-village headman, the peasant cultivator, and the respective lineages of all three. Several of these rights have been asserted in the initial statements of the litigants and the court must now determine who, on balance, is entitled to possession. In its pursuit of a decision (an ensala, a "cutting," Basoga call it, conceptualizing the court's task as one of "cutting through" a tangle of argument and counter-argument), the judges now question the witnesses brought by the litigants.

Walajja, Sulaiti Mukama's witness, says nothing new, merely confirming that Semeyi allotted the land to Sulaiti Mukama and that the latter has occupied it undisturbed for twenty-eight years. Kaswabuli's witness, Eria Bakali, also confirms the testimony of his principal, saying that Kaswabuli inherited the land from his father and grandfather. He adds, however, a statement which may be significant: "When Nandere (Kaswabuli's father) died, he left the land in the hands of his wife, Mpoyendeza, to keep for his son. When Semeyi, the headman, saw that it was in the hands of a mere woman, he cut part of it and gave it to Sulaiti Mukama ...."

Here is a possible lead: the victimization of a poor widow and her child. In the customary law, a minor heir is secure in his rights so long as an adult is named by the lineage as his guardian and trustee. If Semeyi, the headman, took the land from a legitimate minor heir, then the beneficiary of his action has no valid right to the land. The court is aware that this kind of skulduggery on the part of 
headmen is not uncommon; since the headmen get no further income from the land under their jurisdiction so long as it passes down a line of heirs, they sometimes illegitimately seize the land of a minor heir in order to allot it to a new tenant, from whom an allotment fee will be forthcoming. Turning to Walajja, Sulaiti Mukama's witness, the court asks:

Q: From whom did Semeyi get the land which he gave to Sulaiti Mukama?

A: From the old woman, Mpoyendeza.

Here seems to be confirmation, but, curiously, this is not the line which the court pursues. Leaving Sulaiti Mukama, whose position would have been damaged by evidence of such a course of events, it turns to Kaswabuli, who claims to have inherited as a minor:

Q: Before Semeyi died, did you ever accuse him for allotting your kibanja to someone else?

A: I didn't because I was still young.

Q: Sulaiti Mukama says that when Semeyi died you dealt with the matter of another kibanja and that you were given it. Is that so?

A: Yes, we dealt with it and I won.

Q: Why did you not at the time deal with both plots of land if you knew both were yours?

A: Because the first kibanja for which I claimed was taken from me by the village headman, not the sub-village headman Semeyi.

Q: You at first said that Sulaiti had no kibanja and now you say that one was given to him by the sub-village headman, Semeyi. Has he two for which you are claiming, the one you are taking and the one given to him by Semeyi?

A: He has only one, the one given him by Semeyi.

Q: Is that the one in which he says he has spent twenty-eight years?

A: That is the one.

Q: We have heard you say that you were still young at that time, but when did you become old enough to understand the affair of the kibanja?

A: I learned all about it in I935 (sixteen years earlier).

Pressing this line of inquiry, the court turns to Walajja, the sub-village headman and Sulaiti Mukama's witness:

Q: How old was Kaswabuli at his father's death?

A: He had already paid poll tax. ${ }^{10}$

And then to Eria Bakali, Kaswabuli's witness:

Q: In what year did Semeyi give land to Sulaiti Mukama?

A. I don't remember the year.

\footnotetext{
${ }^{10} \mathrm{He}$ was therefore at least eighteen years of age.
} 
By now, both the witness and his principal will have realized what is coming and the witness evades a question to which he almost certainly knows the answer very well. But the court presses the attack:

Q: After the death of Semeyi, did Kaswabuli take the matter before the council of Semeyi's lineage?

A: Yes, he took it before Ziyadi, the lineage head, and Ziyadi demanded a chicken to settle it. ${ }^{11}$

Q: Kaswabuli says that he did not take the matter of the kibanja before the lineage council and now you say he did. Whom shall we regard as telling the truth?

Caught in an inconsistency born of panic, the witness admits that his principal "is telling the truth."

Now the court is satisfied, and after a brief discussion the unanimous decision is given:

The case has been decided and it has gone against the accused, Kaswabuli. In his statement, he has not agreed that it goes against him. The sub-village headman, Walajja, who gave the land to the accuser, and also the witness of the accused, Eria Bakali, have agreed that since Sulaiti Mukama was given the kibanja twenty-eight years have passed. ${ }^{12}$ That is why the case has been decided against the accused. The accuser is given his land. The accused has thirty days in which to appeal to the county court. ${ }^{13}$

Although there is good evidence that Sulaiti Mukama acquired the land through an illegitimate transaction and that Kaswabuli was at that time its rightful owner, the latter's right, the court holds, has lapsed with the passage of time. Kaswabuli has "slept on his remedy."

\section{II}

\section{The Present and Future Position of the Customary Law}

An examination of this case provides us with a brief glimpse into the actual day-to-day operation of the customary law in a contemporary African communitya background against which we may consider more broadly its present and future position.

First of all, it will have become apparent that what is going on in this court room is not simply the application of indigenous law by an indigenous court, unmodified by external forces. The proceedings exhibit many marks of British influence, the result of sixty years of colonial administration. If we are to think realistically about such courts and such law, we must understand the nature of this influence.

\footnotetext{
11 The chicken is a customary symbolic payment to a judge in recognition of his authority.

${ }^{12}$ Eria Bakali did not actually agree, but the court knows that he is aware of the fact.

${ }^{13}$ Kaswabuli did not appeal.
} 
As in most African territories administered by Great Britain, indigenous courts in Uganda have been recognized, and their functions circumscribed, by a series of ordinances, the latest in the case of Uganda being the African Courts Ordinance of 1956. Traditional Busoga was divided among a number of small, but culturally very similar kingdoms, ranging in population from a few thousand to well over one hundred thousand persons. ${ }^{14}$ Each kingdom was headed by an hereditary ruler and each was divided into areas administered by chiefs who were the ruler's clients. Both rulers and chiefs exercised judicial as well as general administrative authority over the people under their jurisdiction, and the two kinds of authority were closely related. The gathering of subordinates in a chief's or ruler's audience hall was a "lukiiko"-a gathering to "kukiika," to "pay homage," and to transact whatever judicial or administrative business was at hand. With the coming of British administration, the District was unified under an African Local Government; and the rulers and chiefs-who were also judges-became its civil servants. Successive courts ordinances, and the rules promulgated under them, recognized courts at what were essentially the traditional levels-now defined as "counties" and "sub-counties"with the chief at each level as chairman; and also established a district court for Busoga as a whole. Although the traditional courts at the lower levels-the village and sub-village headmen's courts-were not formally recognized, they continued to function, as we have seen. Each court of record was given appellate jurisdiction over the courts below it as well as original jurisdiction in successively more serious cases. The whole hierarchy was placed under the revisionary and appellate jurisdiction of the British magistrate's court and the High Court of Uganda. In recent years, a beginning has been made toward separating the judiciary from the administration by appointing special judges, though these have thus far been men drawn from the ranks of the chiefs.

Subject to certain limitations, however, these reorganized courts have been directed by the ordinances to apply "native law and custom," both substantive and procedural, and the British magistrates and High Court judges have been extremely cautious in the exercise of their revisionary and appellate powers in matters of customary law. The customary courts may not try capital cases and may not apply any law which is contrary "to natural justice and morality" or to Protectorate statutes, but the British administration has been content to draw these broad limits and has not attempted to codify or substantively alter the customary law in the spheres which have been left to it. This has meant that in such important fields as land law and family law, the customary courts have throughout the sixty years of British rule exercised an essentially unrestricted jurisdiction.

Legislative enactment and appellate jurisdiction are not, of course, the only sources of British influence. British administrative officers have supervised the courts to the extent of examining their case records-thereby assuring the rather surprisingly high level of recording illustrated in the case discussed above-and have undoubtedly

26 See generally Lloyd A. FaLlers, Bantu Bureaucracy (1956). 
influenced substantive law to some degree through their contacts with chiefs while touring the District. Equally important perhaps, but also difficult to assess, are the consequences of the chiefs' participation in the proceedings of the British magistrates' courts and the High Court. It is the practice in these courts, when Africans appear as litigants, to invite chiefs to sit as "assessors" to advise the court on matters of custom. In the process, as the writer discovered in his conversations with chiefs, the latter observe British court practice and are influenced by it in their conduct of cases in their own courts. Some of the phrases in the case record discussed above which sound like translations of British formulae may be traceable to such experiences.

What we see in operation today, therefore, is a system of courts and a body of law which have deep roots in traditional society and culture but which have been modified, particularly in the direction of more regular organization and procedure, by years of colonial administration. It is significant that such modifications have been slight enough and gradual enough so that the Basoga may feel that these are still their courts and their law. Certainly to the outside observer this appears to be true. One may sit, day after day, observing the courts in action, with very little sense of the intrusion of foreign elements, for these elements-to the considerable extent to which they exist-have been quite thoroughly absorbed. Perhaps the clearest illustration of the care taken by the British administration to protect the integrity of the customary law is provided by the position of customary marriage. A large majority of the Basoga are Christians who contract marriages under the Marriage Ordinance, but the same large majority continue simultaneously to contract customary marriages as well, through the payment of bridewealth. The Protectorate authorities have insisted upon keeping the two processes legally distinct, maintaining the application of customary law to the bridewealth contract irrespective of proceedings regarding the same marriage which may be undertaken under the Ordinance, and have in practice ignored in the case of Africans the prohibition against polygyny which, strictly speaking, should apply to all persons married under the ordinance.

Thus the customary law remains a vigorous and efficient instrument for the adjudication of disputes, particularly in spheres such as land-holding and marriage which are most closely bound up with the village social order. But of course this social order is changing. Important as it is to maintain the continuity and integrity of the law, it is equally important, especially in a society which aspires to rapid modernization, for the law to be sufficiently flexible to adapt to new circumstances.

The courts in Busoga have demonstrated a good deal of such flexibility. For example, prior to Western contact and the spread of literacy, there was in the law of Busoga a quite highly-developed set of rules for establishing the validity of contracts through the oral testimony of witnesses. ${ }^{15}$ As literacy has spread, the courts have apparently quite spontaneously developed new criteria for dealing with

\footnotetext{
${ }^{25}$ These rules are still applied to illiterates.
} 
written documents, such as contracts and simple maps, which have now become a standard feature of marriage and land transactions. Another example is provided by the problems of time limitation-the issue upon which decision in the case discussed above turned. Today all Basoga are no longer peasant farmers. Many spend part of their lives in urban employment, and during World War II many served in the armed forces. As a result of these changes in the occupational structure, there are now new reasons why a man may delay in seeking his rights in inherited land; and particularly since the war, the courts have been developing new criteria in this area.

Thus there is little evidence of a rooted conservatism resistant to the forces of change. But adaptation requires more than a willingness to change; it also requires techniques for maintaining a satisfactory degree of consistency and unity in the law as the various courts applying it encounter and respond to new problems. In the Anglo-American legal tradition, such consistency is maintained through systems of reporting by means of which courts are made aware of precedent-setting decisions. The sixty-odd courts of Busoga form an appellate hierarchy and the notion of precedent is appreciated, but there is no systematic reporting of the decisions of the district court to the lower courts. ${ }^{16}$ As a result, courts in various parts of the District, beginning from a common basis of customary law, may develop divergent adaptations to new conditions. There is evidence that this has happened in the sphere of land law in areas around towns where land is being put to new uses and where forms of buying and selling unknown to traditional customary law are growing up ad hoc. At present a number of countries are experimenting with reporting systems to meet such difficulties. ${ }^{17}$

However, the problems involved in developing effective systems of reporting are formidable. For the case records, admirable as they are in terms of completeness, do not readily lend themselves to analysis and abstraction. African customary law is an excellent example of what Max Weber called "substantive legal rationality."18 Decisions are reached by judges on the basis of an implicit body of normative rules which may be highly consistent internally, but these rules are very seldom made explicit and formally manipulated in the decisions that are rendered. The case discussed above is a splendid illustration of this. The decision states only the barest essentials of the court's reasoning, merely noting that, since Kaswabuli had waited twenty-eight years to claim his rights, the case had gone against him. No mention is made of Kaswabuli's argument, to which the court had devoted a good deal of attention in its quesioning, nor of the process by which the court had concluded that Kaswabuli had neglected to sufficiently press his case.

\footnotetext{
${ }^{10}$ The writer's information on this point may be out of date, but it is safe to say that no effective reporting system exists.

${ }^{27}$ Tanganyika and Kenya, for example.

${ }^{18}$ Max Rheinstein (Ed.), Max Weber on Law in Economy and Society at xlviii (1954). Weber's category of "irrational" (or perhaps "non-rational") might seem more appropriate in view of the implicitness of the reasoning involved, but these terms seem to do violence to the highly consistent system of norms which underlies this implicit reasoning.
} 
In order to determine the complete line of reasoning of a customary court and the full implications of its decision, one must carefully examine and interpret the whole body of testimony. So long as the courts operate with a static or only very slowly changing body of law and set of environing social conditions, this does not matter. But the clear statement and communication of a precedent-setting decision in response to a new problem requires, if such decisions are not to be random departures from tradition, much more explicit formulation of what is being done. The present judges in customary courts are generally incapable of this. While he was studying the customary law of Busoga, the writer found judges unwilling or unable to discuss abstract rules of law, generally responding to his questions by saying that a rule could not be stated in the absence of all the facts of the case. The study, therefore, had to be conducted almost exclusively by inference from decided cases. This kind of inferential analysis would seem to be impossibly laborious and slow for anyone charged with systematic case reporting.

Thus an important requirement for the future health of the customary law would appear to be the development of a corps of judges and clerks well trained in the existing practice of the courts, but trained also in somewhat more analytical modes of legal reasoning. There are, of course, dangers here; care must be taken to avoid arid legalism and the indiscriminate importation of alien concepts not fully understood. But granting these dangers, a somewhat more professionalized bench would nevertheless seem essential if customary law is to be made explicit enough so that its underlying principles may be applied systematically to the new circumstances that will increasingly face it. No doubt there will also arise problems to which the customary law cannot even in the best of circumstances be successfully adapted, and to which, consequently, legislation will be the only answer. But its native tradition of litigation, rooted in the structure of village life, is one of Africa's greatest cultural achievements; and it would seem a pity not to make use of it wherever possible.

\section{ConcLusion}

It is well to remind ourselves, in conclusion, that bodies of customary law of the kind that we have been considering do not stand alone and self-contained in the new states. As we noted at the outset, these states each contain many bodies of such law, and Uganda is no exception to this pattern. At least a dozen distinct customary legal systems exist there, along with elements of British, Indian, and Islamic lawall under the ultimate jurisdiction of the superordinate magistrates' courts and the High Court. Perhaps the most difficult problem of all will be to devise ways of resolving the conflicts of laws that inevitably arise in such situations, while at the same time allowing the customary systems to operate in those homogeneous rural communities to which they are most suitable and which will remain for years to come the social milieu of the majority of Africans. ${ }^{19}$

${ }^{10}$ See Cowen, African Legal Studies-A Survey of the Field and the Role of the United States, supra p. 545, at 552-59; Anderson, The Future of Islamic Law in British Commonucalth Territories in Africa, infra, p. 617 . 